\title{
The Role of PPID in Implementing Policy, Service, Publication of Public Information in State University of Medan
}

\author{
M. Surip, M. Oky Fardian Gafari, Hendra K. Pulungan \\ Lecturer in Faculty of Languages and Arts, State University of Medan, Indonesia
}

\section{Abstract}

The Information and Documentation Management Officer (PPID) at State University of Medan was formed to answer the Minister of Research and Technology Regulation No. 75 of 2016 concerning Public Information Services in the Ministry of Research, Technology and Higher Education. In carrying out its duties as a provider, store, document, and safeguard public information, PPID synergizes with the Cooperation and Public Relations Subdivision which routinely publishes all information through the State University of Medan official website and social media immediately. This research was conducted with the aim of analyzing the role of PPID in carrying out the task of implementing policies, services, and public information publications at Medan State University, as well as analyzing the obstacles encountered and providing solutions to efforts to overcome these obstacles. The method used in this research is descriptive research method. The results showed that based on observations made, it was obtained that more than 70 percent of respondents concluded that they were very satisfied with the public information services provided so far. 2. There are three main substances of the KIP laws and regulations that are used as the main reference for determining the assessment parameters that will be used as an assessment instrument. First, fulfillment of the obligation on information that must be provided and announced periodically in accordance with Article 9 of the FOI Law, which is more detailed in Article 11 of the Information Commission Regulation Number 1 of 2010 concerning Public Information Service Standards (SLIP). The review of information that must be made available and announced periodically is done by means of publication in the form of the main website of the Public Agency with instruments to fulfill the points as stipulated in the KIP laws and regulations. 3. The efforts made by PPID State University of Medan are in overcoming the obstacles faced are: a) Provision of information, b) Information services that are fast, accurate, and simple, in accordance with applicable regulations, c) Determination of operational procedures for disseminating public information, d) Testing of consequences, d) Classification of information, e) Determination of excluded information that has expired, f) Determination of consideration for each policy taken to fulfill the right of everyone to public information.
Keywords

PPID; services; public information; State University of Medan

\section{Introduction}

Law Number 14 of 2008 concerning Openness of Public Information is a legal product issued by the government to regulate the disclosure of public information in state institutions and non-governmental organizations whose funds are partly or wholly sourced from public funds, both the State Revenue and Expenditure Budget / Regional Revenue and Expenditure 
Budget, community contributions, as well as foreign sources. The Law on Public Information Openness requires governments and public bodies to build and develop information and documentation systems so that they are widely accessible to the public. The domain of the right to access information is the right to transparency in the management of public funds / resources, the right to information managed by public bodies, and the right to information to determine the performance of officials in carrying out government functions. According to Karyono (2019) the existence of the government is closely related to the function of public service. Progress in the field of technology and information is one of the challenges for the government in providing more effective, efficient and accountable services. The technology advance characterized by technology digitalization requires the government to better deliver quality of service by utilizing all of the resources the government has and improving performance.

Since the enactment of Law Number 14 of 2008, various results of research / case studies regarding the form of its implementation in realizing public information disclosure have been widely publicized. It's just that the publication is a study conducted by the district / city government. One of them is Pratikno, et al (2012), who conducted a study on the implementation of public information disclosure in various regions, namely East Java, West Papua, Aceh, and DKI Jakarta. The study tried to uncover the level of achievements in each region along with obstacles and opportunities for improvement. This study found a high variation in terms of achievements, both institutional achievements through the installation of the Regional Information Commission and the Information Management and Documentation Officer, as well as substantive achievements directly related to the availability of public information, the means to access and the level of access. The variation in achievements is influenced by various factors, ranging from limited socialization related to public information disclosure, limited capacity of the implementer, to systematic resistance to refusing its implementation.

After the enactment of the Act, Minister of Research, Technology also issued Minister of Research, Technology and Higher Education Regulation No. 75 of 2016 concerning Public Information Services at the Ministry of Research, Technology and Higher Education. Following the Regulation, State University of Medan formed an Information and Documentation Management Officer (PPID) whose task was to carry out the process of gathering, processing, presenting, documenting, reporting, and providing public information services at State University of Medan.

PPID State University of Medan is responsible for the field of public information services which include storing, documenting, providing and providing public information. PPID is responsible for coordinating the storage and documentation of all public information in the Public Agency (State University of Medan). Within the framework of responsibility, PPID has the task of coordinating the collection of all physical public information from each unit / channel of work which includes: a) Information that must be provided and announced periodically, b) information that must be available at any time, and c) other open information that requested information applicant public.

Some research results related to Information Services conducted by PPID, in general there are several constraints / obstacles related to public information service institutions, such as: 1) the still weak culture of documenting information on the activities and outputs of the performance of most public bodies. 2) Weak appreciation and treatment of information for improving the quality of life of the community. 3) The still weak organizational administration system in most public bodies which results in a lack of orderly flow of 
information within the public body itself. 4) The still weak information management system in the public body environment so that the mechanism of "retrieving" information for public services often experience difficulties, 5) There is still a "gap" that is large enough to the quality of information services among public bodies making it difficult to determine a standard for the quality of information service mechanisms. 6) Systematic processes for handling public information services are still systematic, both at the central, regional, and between central and regional levels (Aklaf Idrus, 2002).

Based on some of the explanations mentioned above, we can see that this State University of Medan Information and Documentation Management Officer has a very vital role in the administration of Services as well as in terms of Provision of Information in the framework of Implementing Law Number 14 Year 2008 in general, and Regulation Of The Minister Of Research, Technology, And Higher Education Number 75 Year 2016 specifically within the Ministry of Research and Technology. For this reason, this research wants to analyze the extent to which the role and function of this PPID can run according to the provisions in State University of Medan.

The concept of openness in service refers to a situation where all aspects of the service delivery process are open and can be easily accessed by service users and stakeholders in need. If all aspects of service delivery, particularly those relating to rights and obligations between service providers / service providers and service users can be easily accessed and publicly published so that it is easily understood by the public, then the practice of such service has a high level of openness, such as: requirements, time, costs, service flow, complaints mechanisms and so on. Conversely, when all or part of the service aspects are not open and difficult to access by service users or stakeholders, the service delivery has a low level of openness, or in other words does not meet the rules of openness (Suharno, 2006: 18).

Public information services in tertiary institutions are regulated in Minister of Research, Technology and Higher Education Regulation Number 75 of 2016 concerning Public Information Services in the Ministry of Research, Technology and Higher Education. In the Regulation of the Minister of Research, Technology, And Higher Education, the intended public information is information that is generated, stored, managed, sent, and / or received by the Information Management and Documentation Officer (PPID) relating to the administration and administration of the state, as well as other information relating to the public interest.

Ministry of PPID and PTN Legal Entity PPID as referred to in Article 3 paragraph (1) letter $\mathrm{b}$ and Article 4 paragraph (1) letter $\mathrm{b}$ has the duty and authority to: (a) collect, provide, store, document, and secure information; (b) provide public information services that are fast, accurate, and simple in accordance with statutory provisions; (c) establish operational procedures for disseminating public information; (d) establish exempt information based on a consequence test; (e) determine the classification of public information and / or change it; (f) designate exempted public information that has exhausted its time period as publicly accessible information; (g) determine written considerations for each policy taken to fulfill everyone's right to Public Information; (h) coordinate with the Implementing PPID; (i) provide guidance to the Implementing PPID; and (j) evaluating the Implementing PPID. 


\section{Research Method}

The research method used to answer this research is a descriptive research method with a qualitative approach. Narbuko and Achmadi (2004: 44) provide descriptive research understanding as research that seeks to tell the current problem solving based on data, so he also presents data, analyzes and interprets; it can also be comparative and correlative. Taylor and Bogdan in Danim (2002: 41) say that qualitative research can be interpreted as research that produces descriptive data on spoken and written words, and observable behavior of the people studied. The data needed in this study are primary data and secondary data. Primary Data, namely data directly obtained from the field obtained through observation and interviews. Furthermore, data was collected through interviews, questionnaires, and observations.

\section{Result and Discussion}

An overview of the results of the research The Role of PPID in Implementing Policies, Services, and Public Information Publications at Medan State University can be explained through several answers to the formula of the problems proposed in the introductory chapter, namely: 1) Describe the role of PPID in implementing policies, services, and information publications public at State University of Medan. 2) Analyze the constraints faced by PPID in implementing policies, services, and public information publications at State University of Medan, and 3) explain the various efforts undertaken by PPID to overcome obstacles faced in implementing policies, services, and public information publications at State University of Medan.

\subsection{Publication of Public Information at State University of Medan}

Information and data are not only the basic needs of everyone for personal and social development, but also become an orderly supporter of administration in realizing good governance. The right to obtain information has become a human right, therefore public information disclosure is an important feature of public bodies carrying out their duties and functions properly in accordance with applicable laws and regulations. State University of Medan as a Public Agency certainly has the information needed by the Public. The various tasks carried out by State University of Medan are closely related to people's lives, especially in the field of Higher Education services, therefore information on the results of the organization, management and implementation of tasks in the field of higher education is needed by the public. Therefore, one of the strategic steps taken by State University of Medan is to appoint an Information Management and Documentation Officer (PPID) in the State University of Medan environment. So that in accordance with the Regulation of the Minister of Research, Technology and Higher Education of the Republic of Indonesia Number 75 Year 2016 Regarding Public Information Services in the Ministry of Research, Technology and Higher Education.

State University of Medan PPID routinely publishes all information through the State University of Medan website. Most information about State University of Medan can be accessed and downloaded for free from the State University of Medan website page. Regarding other information that is not available, the public can request it by making a written request to the State University of Medan PPID Office or State University of Medan Integrated Information and Services Center (PINTU) through direct mail, electronic mail or 
in other ways according to regulations. The information available is generally free without charge, unless otherwise specified.

\subsection{State University of Medan PPID Service Vision, Mission, Objectives, Motto and Information}

\section{a. Vision}

Become an independent, transparent and accountable public servant to support the development of Medan State University towards a world class university.

\section{b. Mission}

1) Improve the management and service of public information that is open and quality;

2) Develop and develop a system of providing and service information effectively and efficiently;

3) Implement and provide public information services that refer to the Medan State University strategic plan;

4) Develop an integrated management information system;

5) Providing information services that can be accessed by all parties;

6) Improve the quality of public information services through the availability and ease of access to information in a fair, equitable, and accountable manner

\section{c. Purpose}

1) Trying to improve the management and service of public information openly.

2) Providing public information services in a professional, easy, transparent and open manner.

3) Develop, provide and provide public information services for the community.

4) Making decisions on information accessible or not accessible to the public based on a consequence test together with the PPID Minister of Research, Technology supervisor.

5) Facilitating and rejecting requests for Public Information in writing if the requested Public Information includes Exempt Public Information accompanied by reasons as well as notification of the rights and procedures for the applicant to submit an objection to the refusal.

6) Coordinate with PPID instruments and / or related units in resolving dispute disputes.

\section{d. Motto}

The service motto is in accordance with the motto of Medan State University, namely: "Do something right and sincere"

\section{e. Notice of Service}

The service notice is in accordance with the public service notice of Medan State University, namely:

"We hereby declare that we are capable of providing services in accordance with the services set and if we do not keep this promise we are ready to receive sanctions in accordance with the applicable laws and regulations" 
3.3 The Role of PPID in Implementing Public Information Policy, Services and Publications at State University of Medan

Based on a survey conducted by the Public Information Management Team, the Public Information Service of the State University of Medan on the Level of Satisfaction of users or applicants of public information, it can be conveyed that there are two (2) responses in the form of filling out the State University of Medan public information service satisfaction questionnaire from a total of five (5) applicants for public information at State University of Medan. As for each of these results, namely:

\section{a. Respondent Workplace Institution}

PPID State University of Medan receives requests for public information from individuals and institutions. The two (2) applicants for information came from the Institution. Each of the respondents is female

\section{b. Public Information Services at PPID State University of Medan}

The results of the questionnaire stated that the Public Information service at Medan State University was good, and was very helpful for respondents in doing work, so that respondents would recommend the PPID State University of Medan service to applicants for other information.

\section{c. Possibility of Submitting a Request for Public Information Back}

After stating that the public information service at Medan State University was good, the respondent stated that it would be possible to re-submit a request for public information to PPID State University of Medan.

\section{d. Most Liked Service}

Based on the questionnaire we received, respondents preferred requests for public information online or by using e-mail, websites, or apps in accordance with the information available in the procedure for requesting public information.

\section{e. Most Liked Service}

Based on the questionnaire we received, the respondent did not give complaints or unwanted experiences to PPID State University of Medan.

\section{f. General Assessment}

Based on the questionnaire that we got, respondents gave a good and very good average to PPID State University of Medan.

2.4 Efforts made by PMI to overcome obstacles faced in implementing policies, services, and public information publications at State University of Medan

Based on Article 7 of Law No. 14 of 2008 concerning Openness of Public Information, Public Agencies have the following obligations: (1) Public Agencies must provide, provide and / or publish Public Information under their authority to the Public Information Applicant, in addition to information that is excluded in accordance with the provisions. (2) Public bodies must provide public information that is accurate, correct and not misleading. (3) In order to carry out the obligations referred to in paragraph (2), the Public Agency must establish and develop an information and documentation system to manage Public Information properly and efficiently so that it can be easily accessed. (4) Public bodies must 
make a written consideration of each policy taken to fulfill the right of everyone to public information. (5) The considerations referred to in paragraph (4) include but not limited to political, economic, social, cultural and / or national defense and security considerations. (6) In the framework of fulfilling the obligations as referred to in paragraph (1) through paragraph (4) a Public Body may utilize electronic and non-electronic means and media.

A description of the Obligations of Public Agencies as mandated by Law No. 14 of 2008 is in Article 4 of Information Commission Regulation No. 1 of 2010 concerning Public Information Service Standards (SLIP) that Public Agencies have the following obligations: a. establish regulations regarding the standard operating procedures for Public Information services in accordance with this Regulation; b. build and develop information and documentation systems to manage Public Information properly and efficiently; c. appoint and appoint PPID to carry out their duties and responsibilities and authorities; d. allocate adequate funding for Public Information services in accordance with applicable laws and regulations; e. provide facilities and infrastructure for Public Information services, including notice boards and information desks in every office of the Public Agency, as well as the official website for the State Public Agency; f. set a standard cost of obtaining copies of Public Information; g. establishing and regularly updating the List of Public Information of all Public Information that is managed; h. provide and provide Public Information as regulated in this Regulation; i. provide responses to objections raised by Public Information Applicants who file objections; j. make and announce reports on Public Information services in accordance with this Regulation and submit a copy of the report to the Information Commission; and K. evaluating and supervising the implementation of Public Information services on its institution. The efforts made by PPID State University of Medan are: (1) Provision of information, (2) Fast, accurate, and simple information services, in accordance with applicable regulations, (3) Determination of operational procedures for disseminating public information, (4) Testing of consequences, (5) Classification of information, (6) Determination of excluded information that has expired, (7) Determination of the consideration of each policy taken to fulfill everyone's right to public information.

\section{Conclusion}

Based on the formulation of the problem, the results of data analysis and discussion in this study, the following conclusions can be drawn.

1. Based on observations made information obtained that more than 70 percent of respondents concluded very satisfied with the public information services provided so far.

2. There are three main substances of the KIP laws and regulations which are used as the main reference for determining the assessment parameters that will be used as an Assessment instrument. First, fulfillment of the obligation on information that must be provided and announced periodically in accordance with Article 9 of the FOI Law, which is more detailed in Article 11 of the Information Commission Regulation Number 1 of 2010 concerning Public Information Service Standards (SLIP). The review of information that must be made available and announced periodically is done by means of publication in the form of the main website of the Public Agency with instruments to fulfill the points as stipulated in the KIP laws and regulations.

3. The efforts made by PPID State University of Medan are in overcoming the obstacles faced are: a) Provision of information, b) Information services that are fast, accurate, and simple, in accordance with applicable regulations, c) Determination of operational 
procedures for disseminating public information, d) Testing of consequences, d) Classification of information, e) Determination of excluded information that has expired, f) Determination of consideration for each policy taken to fulfill the right of everyone to public information.

\section{References}

Agus Dwiyanto. (2005). Mewujudkan Good Governance Melalui Pelayanan Publik. Yogyakarta: Pustaka Pelajar.

Achmadi dan Narbuko (2004). Metode Penelitian. Jakarta: Bumi Aksara.

Danim, Sudarwan. (2002). Menjadi Peneliti Kualitatif; Ancangan Metodologi, Presentasi, dan Publikasi Hasil Penelitian untuk Mahasiswa dan Peneliti La Bidan Ilmu Ilmu Sosial, Pendidikan, dan Humaniora. Bandung: CV. Pustaka Setia.

Karyono, O., Agustina, K. (2019). Determining the Priority Strategy in the Implementation of E-Government Through Swot Analysis Model. Budapest International Research and Critics Institute (BIRCI-Journal), 2(2); 66-74.

Moleong, Lexy. (2002). Metodologi Penelitian Kualitatif. Bandung: PT. remaja Rosdakarya. Pratikno, et al. (2012). Kajian Implementasi Keterbukaan Informasi Publik dalam Pemerintahan Lokal Pasca Undang-Undang Nomor 14 Tahun 2008. Cetakan Pertama. Yogyakarta: Yayasan Tifa dan Fisipol UGM Yogyakarta.

Peraturan Menteri Riset, Teknologi dan Pendidikan Tinggi Nomor 59 tahun (2016) tentang Pelayanan Publik di Kementerian Riset, Teknologi dan Pendidikan Tinggi

Suharno. (2013). Dasar-dasar Kebijakan Publik. Yogyakarta: Ombak.

Sugiyono, (2008). Metode Penelitian Kunatitatif Kualitatif dan R\&D. Bandung Alfabeta. Undang-Undang RI Nomor 14 Tahun (2008) Tentang Keterbukaan Informasi Publik Undang Undang Nomor 25 Tahun (2009) tentang Pelayanan Publik. 